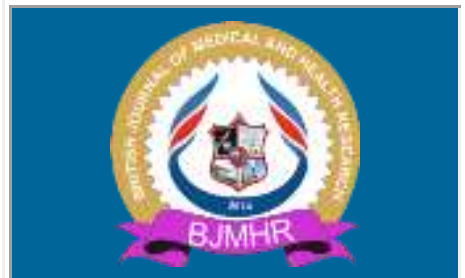

\title{
BJMHR
}

British Journal of Medical and Health Research

Journal home page: www.bjmhr.com

\section{Phytopharmacology Profile of Bougainvillea glabra: An Overview}

\author{
Shweta Sehrawat*, Himesh Soni \\ GVM College of Pharmacy, Murthal Road, Sonepat. DHS, Bhopal(M.P.)
}

\section{ABSTRACT}

Plants are a source of huge amount of drugs compromising to different groups such as anti diabetic, antispasmodics, emetics, anti-cancer, anti-microbial etc. The WHO estimated that $80 \%$ of the population of developing countries still relies on traditional medicine, mostly plant drugs for their primary health care needs. Paper flower is the other name used for the Bougainvillea. Bougainvillea is a popular woody scandent shrub. The leaves of Bougainvillea glabra are reported to have anti- inflammatory activities, anti-hyperglycemic activity, insecticidal activity, anti hyperglycemic activity anti ulcer, antimicrobial and anti-diarrheal activity and its antiviral proteins. This review spotlights the recent updates on Bougainvillea glabra with reference to their morphology, phytochemistry and phytopharmacology.

Keywords: Bougainvillea glabra (B.glabra), bioactive constitute, phytochemical, pharmacological 


\section{INTRODUCTION}

Medicinal plants are of great significance to the health of individuals and communities. India is well known as the "Emporium of Medicinal Plants". Due to their great importance, demand of medicinal plants has increased numerous folds ${ }^{1}$. Bougainvillea genus is an incredibly widespread group throughout the world. It belongs to the family Nyctaginaceae and, according to the "The Plant List", contains approximately18 species ${ }^{2}$. The objectives of this review are to provide recent update on Bougainvillea glabra with emphasis on their morphological characteristics features along with their phytochemistry and pharmacological activity. Bougainvillea was named after the world traveler, Louis de Bougainville, who discovered it in Brazil in 18th century and brought it to Europe where it became both widespread and popular ${ }^{3}$. Bougainvillea commonly name as the paper flower owing to bracts are thin and papery.

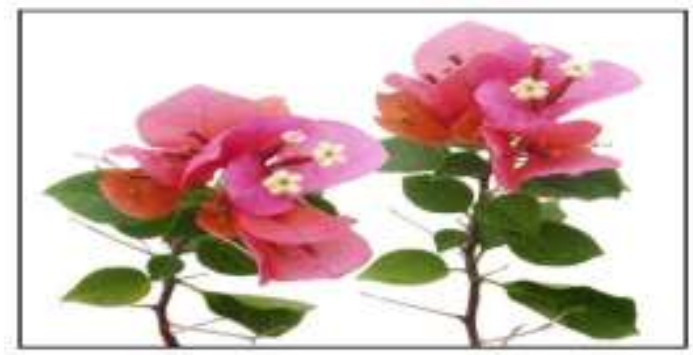

\section{Bougainvillea glabra}

Botanical description of B.glabra

\begin{tabular}{|c|c|c|c|}
\hline Ethnobotany & Vernacular names & Uses & Reference \\
\hline Taxonomical Classification & English: $\quad$ Lesser & Coughing and & $4-8$ \\
\hline Kingdom: & Bougainvillea/Paper & Pertussis & \\
\hline Subkingdom: & flower & For the treatment of & \\
\hline Tracheobionta & - Hindi: Booganbel & asthma, bronchitis, & \\
\hline Superdivision: & - Manipuri: Cherei & and dysentery. & \\
\hline Spermatophyta & - Bengali: Baganbilas & It also indicated for & \\
\hline Magnoliophyta & - Marathi: Booganvel & stomach pain, rust, & \\
\hline Magnoliopsida & Konkani: & pimples, & \\
\hline Caryophyllidae & Bouganvila & blackheads & \\
\hline Caryophyllales & - Telugu: Kagithala & & \\
\hline Nyctaginaceae & Puvvu & & \\
\hline Genus: Bougainivillea & & & \\
\hline
\end{tabular}

Morphological description of $B$. glabra $^{9-10}$

\begin{tabular}{|l|l|l|}
\hline Leaves & Flower & Tree \\
\hline
\end{tabular}




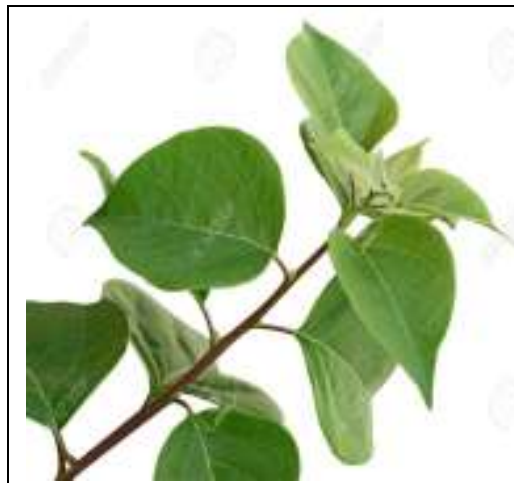

The leaves are alternate, simple ovate-acuminate.

Generally, 4-13 cm long and $2-6 \mathrm{~cm}$ broad.

Leaf Arrangement: Alternate Leaf

Venation: Pinnate

Leaf Persistence: Evergreen Leaf

Type: Simple

Leaf Blade: Less than 5

Leaf Shape: Lanceolate

Leaf Margins: Undulate Leaf

Textures: Smooth

Leaf Scent: No Fragrance

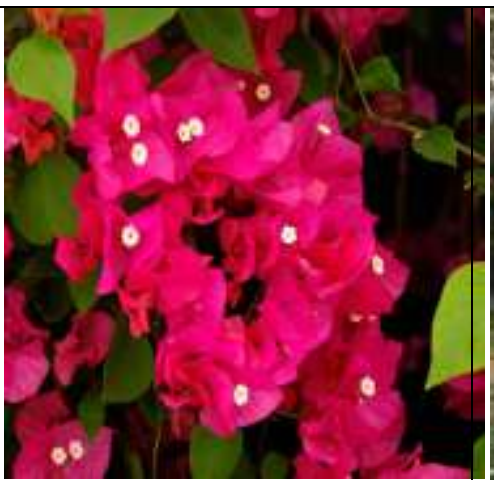

Flower of the plant is small and generally white, but each cluster of three flowers is surrounded by three or six bracts with the bright colors associated with the plant, including pink, magenta, purple, red, orange, white, or yellow.

Flower Showiness: True

Flower Size Range: 0 - 1.5

Flower Type: Solitary

Flower Sexuality:

Monoecious (Bisexual)

Flower Scent: No

Fragrance

Flower Color: Yellow,

Orange, Red, Purple,

Variegated, White

Seasons: Spring, Summer

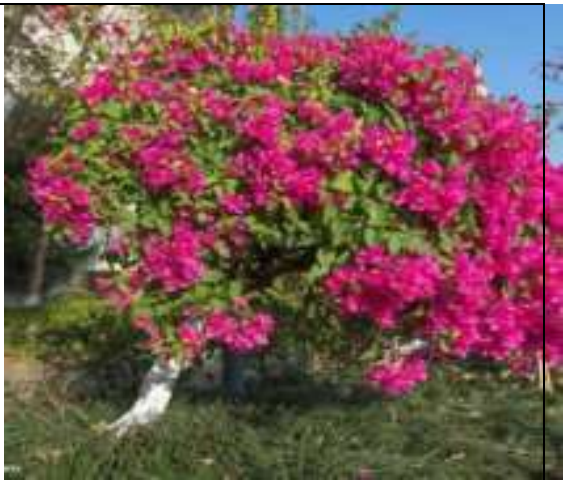

Evergreen, climbing woody vine. Its grows $1-12 \mathrm{~m}$ ( $4-40 \mathrm{ft})$.

The woody trunk tends to be twisted and the thin stem has sharp thorns and dark green leaves.

\section{Phytochemistry of $B$. glabra}

Preliminary phytochemical screening of leaves in different extracts revealed the presence of alkaloid, glycosides (minute amount), flavanoids, tannins, steroid, protein and saponins ${ }^{11}$.B.glabra is rich source of Phenolic compounds present in flower and leaves. Some example of compounds are as follows.

\begin{tabular}{|l|l|l|}
\hline B. glabra Flowers & B. glabra Leaves & Reference \\
\hline
\end{tabular}




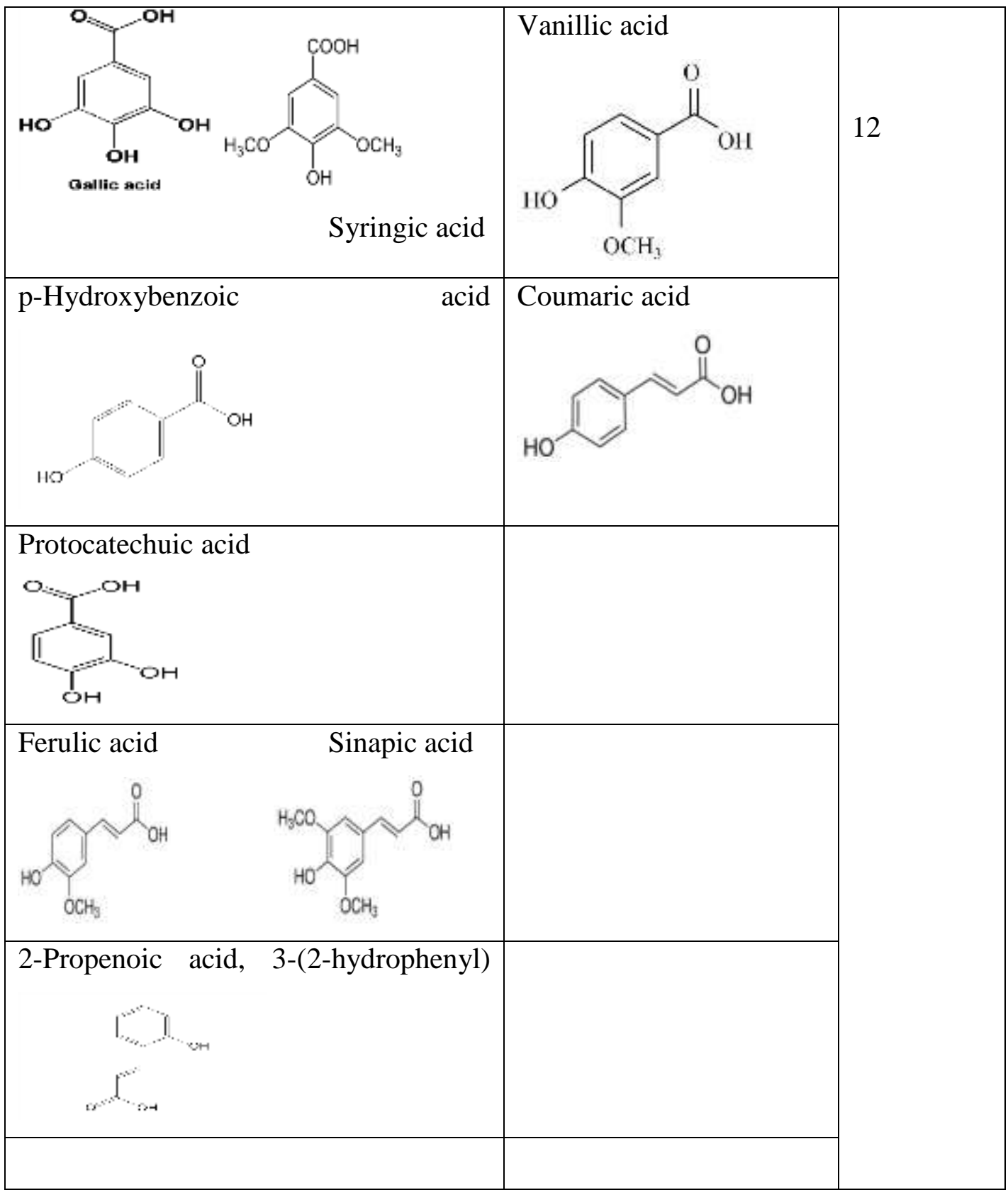

Various types of flavanoids reported in the B.glabra. They are as follows.

\begin{tabular}{|l|l|l|l|}
\hline B. glabra Flowers & B. glabra Leaves & Reference \\
\hline Rutin & Quercetin & Isovitexin \\
\hline Apigenin & Vitexin B \\
\hline
\end{tabular}




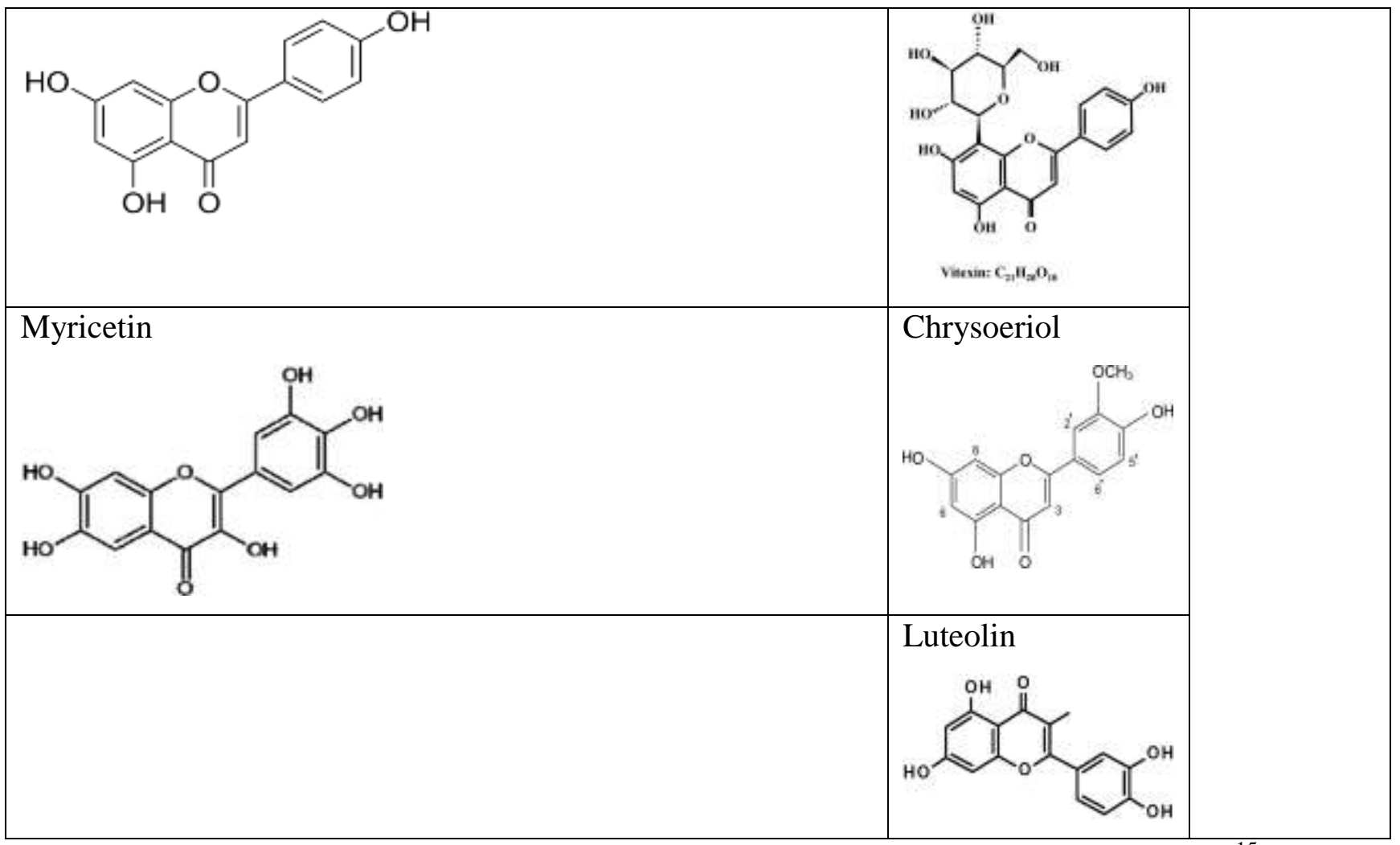

Other important constituent present in B.glabra responsible for their therapeutic activity are ${ }^{15-}$ 16

\begin{tabular}{|l|l|l|}
\hline \multicolumn{1}{|c|}{ Name } & \multicolumn{1}{|c|}{ Nature } & \multicolumn{1}{c|}{ Activity } \\
\hline $\begin{array}{l}\text { 3-o-methyl-d-glucose } \\
\text { tetradecanoic acid, ethyl ester }\end{array}$ & Sugar moiety & Anti cancer ,hypocholestrolemic \\
\hline Phytol & diterpene & Antiinflamatory, antioxidant \\
\hline $9,12,15$-octadecatrienoic acid & $\begin{array}{l}\text { Linolenic acid } \\
\text { ester }\end{array}$ & $\begin{array}{l}\text { Hypocholestrolemic } \\
\text {,hepatopeotective, antiacne }\end{array}$ \\
\hline Squalene & Triterpene & $\begin{array}{l}\text { Antibacterial, antioxidant, immuno } \\
\text { stimulant, Chemoprotective }\end{array}$ \\
\hline Vitamine E & Vitamine & $\begin{array}{l}\text { Antidiabetic, analgesic, antioxidant, } \\
\text { hepatoprotective }\end{array}$ \\
\hline
\end{tabular}

\section{Phyopharmacology of B.glabra}

Bouainvillea glabra shows Antiulcer activity ${ }^{17}$, Antidiarrheal activity ${ }^{18}$, Antimicrobial activity and for cough \&sore throat treatment. Plant also used for heptatitis and leucorrhea treatment, Act as antacid for reducing acidity ${ }^{18}$. However B. glabra also shows Antibacterial activity ${ }^{19}$, Antidiabetic activity ${ }^{20}$, Antifertility activity ${ }^{21}$. Moreover Bougainvilea also possess Antioxidant activity ${ }^{22}$ Antiinflammatory activity ${ }^{23}$.

Previous Studies carried out on Bougainvillea Glabra 
The anti-bacterial action of various extracts of Bougainvillea glabra 'Choicy' leaves may indicate their potential as antibacterial herbal remedies. Now there is use of these plants in the therapy against disease caused by the test bacterial species and other micro-organisms. It is possible that better therapy for many microbial diseases can be found in the leaves extracts. The preliminary results of this investigation indicates that Bougainvillea glabra 'Choicy' and Bougainvillea glabra 'Snow White' leaves have good potential of antimicrobial activity ${ }^{24}$. Investigation the anti-helmintic activity of different extracts of leaves of Bougainvillea glabra using petroleum ether, ethyl acetate methanol and water as solvents was carried out . Various concentrations ( 25 and $50 \mathrm{mg} / \mathrm{ml}$ ) of all the extracts were tested, which involved determination of time of paralysis and time of death of the worms. It was compared with Albendazole as standard reference and normal saline as control. The study indicated the potential usefulness of Manihot esculenta against earthworm infections. Anthelmintic activity of Bougainvillea glabra is confirmed by examining the time taken for paralysis (P) and death (D) for Pheretima posthuma worms were reported. methanolic extract of Bougainvillea glabra exhibited anthelmintic activity in dose dependent manner taking shortest time for paralysis $(\mathrm{P})$ and death (D) with $50 \mathrm{mg} / \mathrm{ml}$ concentration.so, it was observed that methanolic extract was more potent than the other three extracts (petroleum ether, ethyl acetate and water) even though chloroform and ethyl acetate extracts were not accomplished with anthelmintic property when compared with control and standard group. Thus, the activity revealed concentration dependence nature of the different extracts. It could be concluded that methanolic extract of Bougainvillea glabra showed most potent anthelmintic activity ${ }^{25}$.

The studied carried out on ethanolic extract of B. glabra bract (EEBGB) to assess the antioxidant potential using 4 different antioxidant pathways, quantification of phenolics, flavanoids and betalains. The EEBGB showed high antioxidant activity (IC50)in DPPH free radical scavenging activity and superoxide radical scavenging. The EEBGB possessed good reducing power in FRAP (105.37 $\pm 5.3 \mathrm{mg}$ TE/100 g of extract) and antioxidant capacity with ORAC score of $166,920 \pm 27,962 \mu \mathrm{M}$ TE/100g ${ }^{26}$.

Investigation of anti-hyperlipidemic activity was carried out on the extract of Bougainvillea glabra leaves against triton induced hyperlipidemia in rats. Ethanolic extract, aqueous extract, chloroform fraction of ethanolic extract and ethylacetate fraction of ethanolic extract administered at different doses to the triton induced hyperlipidemic rats. Bougainvillea glabra has shown a significant decrease in the levels of serum cholesterol, triglyceride, LDL and significant increase in the level of serum $\mathrm{HDL}^{27}$.

The antidiabetic and antilipidemic effects of Bougainvillea glabra was investigated in this study using 25 male wistar rats.. The results revealed that the extract significantly $(\mathrm{p}<0.05)$ reduced 
the hyperglycaemia from $12 \pm 0.40 \mathrm{mmol} / \mathrm{L}$ (Diabetic Control) to $4.04 \pm 0.03 \mathrm{mmol} / \mathrm{L}(400$ $\mathrm{mg} / \mathrm{kg}$ group). Likewise, the extract significantly reduced the Total Cholesterol (TC), Triglyceride (TG) and Low-Density Lipoprotein Cholesterol (LDL Cholesterol), while increasing the High-Density Lipoprotein Cholesterol (HDL-C). In conclusion, the observations from this study show that Bougainvillea glabra has antidiabetic effect and beneficial effects on blood lipid profile, thus justifying the use of the plant by traditional medicine practitioners for the treatment of diabetes mellitus ${ }^{28}$.

The work was establish to assess the properties of Bougainvillea glabra leaf extract and chitin synthesis inhibitor, flufenoxuron on larvicidal and pupicidal activity against the paddy army worm, Spodoptera mauritia. The methanol extract of B. glabra leaves showed larvicidal and pupicidal activity, after $24 \mathrm{~h}$ of exposure; against third- to sixth- instar larvae and pupae of S. mauritia, with obtained values of $\mathrm{LD} 50=5.340 \%$ in $3 \mathrm{rd}$ instar, $9.730 \%$ in 4 th instar, $14.891 \%$ in 5 th instar and $18.755 \%$ in 6th and $21.468 \%$ in pupae respectively. Moreover, combined treatment of the B. glabra and flufenoxuron LD50 values of 3rd instar was $0.638 \%, 4$ th instar was $1.571 \%$, 5th instar was $2.475 \%$, and 6 th instar was $4.768 \%$, and pupae was $8.266 \%$, respectively. The results showed the leaves extract of B. glabra and insect growth regulator, flufenoxuron are best choice for controlling Spodoptera mauritia. Hence, B. glabra and flufenoxuron can be considered for eco-friendly pest control programs ${ }^{29}$.

Anti-diarrhoeal and reducing anti-oxidant power of Bougainvillea glabra "Snow White" was carried out. An animal study (antidiarrhoeal activity) was carried on experimental albino rats. Extract of leaf was extracted by soxhlet apparatus by using hydro alcoholic solvent (50:50). hydroalcoholic extract in $200 \mathrm{mg} \mathrm{kg-1}$ and $400 \mathrm{mg} \mathrm{kg-1}$ doses were administered in two group and loperamide was administered in dose $3 \mathrm{mg} \mathrm{kg}-1$ in separate group. After $5 \mathrm{~h}$ fecal matter was collected and test groups were compared with those in the control animals and analyzed statistically. The extracts were shown anti diarrhoeal activity and reducing antioxidant power. These activities were statistically significant $(\mathrm{P}<0.05)$ when compared with control. These results suggest that Bougainvillea glabra "Snow White" is able to reduce free radical and effective in bowl imbalance ${ }^{30}$.

\section{Acute toxicity studies}

The acute toxicity studied were carried out by Gupta etal $^{31}$ and the extracts were safe up to the dose of $2000 \mathrm{mg} \mathrm{kg}^{-1}$.

\section{CONCLUSION}

This review focus the ethno-medical, phytochemical, pharmacological and toxicological uses of the Bougainvillea glabra. The plant showed potential source of natural antioxidant due to presence of various bio-active substances which neutralizes free radicals which could cause 
oxidative damage of cell membranes and DNA and thereby possess various pharmacological effects.

\section{REFERENCE}

1. Himesh Soni, A.K. Singhai. RECENT UPDATES ON THE GENUS COLEUS : A REVIEW. Asian J Pharm Clin Res, 5(1), 2012, 12-17.

2. K. D. Kobayashi, J. McConnell, and J. Grifs, Bougainvillea. Ornamentals and Flowersk,

Available at: http://scholarspace .manoa.hawaii.edu/bitstream/10125/2959/1/OF-38.pdf., 2007.

3. Cowan DV, Flowering trees and shrub in India, 6 th ed., Messrs Thacker \& Co., 1952, 75.

4. R. Gobato, A. Gobato, and D. F. G. Fedrigo, "Study of the molecular electrostatic potential of D-Pinitol an active hypoglycemic principle found in Spring flower-Tree Marys, (Bougainvillea species) in the Mm+ method," Parana Journal of Science and Education, vol. 2, pp. 1-9, 2016.

5. N. Sahu and J. Saxena, "Bougainvillea glabra a Natural Antioxidant: A Review," Chemistry, vol. 46, pp. 4113-4117, 2012.

6. Flowers of india.net/catalog/slides/Bougainvillea.html.

7. C. Monroy-Ortiz and R. Monroy, "Las plantas, companeras de siempre: la experience en Morelos," (UAEM, Centro de Investigaciones Biologicas de la CONABIO CONANP), 2006.

8. Argueta Villamar, L. M. Cano Asseleih, and M. L. Rodarte, Atlas de las plantas de las Medicina Tradicional Mexicana, Instituto Nacional Indigenista, 1994.

9. landscapeplants.aub.edu.lb/Plants/GetPDF/38f28348-43e0-4963-9270.

10. Usher G, Dictionary of plants used by man constable ISBN0094579202. Lists a very extensive range of useful plants from around the world with very brief details of the uses, 1974.

11. V. Gupta, M. George , M. Singhal , L. Joseph , H. Arya. Pharmacognostical Evaluation of the Leaf of Bougainvillea glabra 'Snow White' Journal of Pharmacy Research 2009, 2(11),1775-1779.

12. Rodolfo Abarca-Vargas and Vera L. Petricevich. Bougainvillea Genus: A Review on Phytochemistry, Pharmacology, and Toxicology. Evidence-Based Complementary and Alternative Medicine. 2018,17

13. H. Ahmed, "New flavone from the aerial parts of Bougainvillea glabra," International Journal of Computer Engineering Research, vol. 4, pp. 1-5, 2014. 
14. O. Kaisoon, I. Konczak, and S. Siriamornpun, "Potential health enhancing properties of edible flowers from Thailand," Food Research International, vol. 46, no. 2, pp. 563$571,2012$.

15. Koleva II, van Beck TA, Linssen JPH, de Groot A, Evstatieva LN. Screening of bougainvillea glabra plant extract for antioxidant activity. Phytochemical Analysis. 2002; 13: 8-11.

16. Rajeshwari R, Thejomoorthy P. Internatinal conference on traditional drug in disease management, SASTRA universm, Thanjavur, tamilnadu, India. International pharmaceutical sciences. 2006; 4(2): 12-14.

17. Rajeshwari R, Thejomoorthy P. International conference on traditional drug in disease management, SASTRA universm, Thanjavur, tamil nadu, India. International pharmaceutical sciences. 2006; 4(2): 15-16.

18. Edwin, Sheeja E, Toppo E, Tiwari V, Dutt KR. Antidiarrheal activity of bougainvillea glabra leaves extract. Ars pharaceutica. 2007; 48(2): 135-144.

19. Umamahesheswari A, Shreevidya R, Nuni A. In vitro Anti bacterial activity of bougainvillea spectabilis leaves extracts. Advance Biological Research. 2008; 2: 1-5.

20. Narayanan CR, Joshi DD, Mujumdar AM, Dhekne VV. Pinitol-A new antidiabetic compound from the leaves of Bougainvillea spectabilis. Current Science. 1987; 56: 139-141.

21. Mishra N,Joshi S, Tandon VL, Munjal A. Evaluation of Anti fertility potential of aqueous extract of Bougainvillea spectabilis leaves in swiss albino mice. International journal of pharmaceutical science and drug research.2009; 1: 19-23.

22. Balandrin MF, Klocke JA, Wutule ES. Evaluation of antioxidant potential of B.spectabilis in wistar rats. WH Bollinger Science. 1985; 228: 1154-1160.

23. Joshi DD, Mujumdar AM, Narayana CR. Anti inflammatory activity of Bougainvillea spectabilis leaves. Indian journal of Pharmaceutical Sciences. 1984; 46: 187-188.

24. Gupta V, George M. , Joseph L., Singhal, M.Singh. Evaluation of antibacterial activity of Bougainvillea glabra 'snow white' and Bougainvillea glabra 'choicy'. Journal of Chemical and Pharmaceutical Research, 2009, 1(1): 233-237.

25. M. Chinna Eswaraiah, A.Elumalai, Anil Boddupalli and Ravi Kiran Gollapalli. Evaluation of Anthelmintic Activity of bougainvillea glabra Leaves. NTERNATIONAL JOURNAL OF DRUG DISCOVERY AND HERBAL RESEARCH (IJDDHR) 2(1): (2012), 272 -274

26. Shalini M , Aminah A, Khalid HM , Vimala S, Katherine S , and Khoo MGH. In-vitro Antioxidant Activities, Phytoconstituent and Toxicity Evaluation of Local 
Bougainvillea glabra Bract (Bunga Kertas). /International Journal of ChemTech Research, 2018,11(09): 22-30.

27. Brajesh Garg, N. M. Srivastava and Savita Srivastava. Antihyperlipidemic effect of Bougainvillea glabra leaves in triton wr-1339 induced hyperlipidemic rats. Der Pharmacia Lettre, 2015, 7 (7):187-190.

28. Adebayo, Oluwakemi T. Alabi, Bamidele V. Owoyele* and Ayodele O. Soladoye. Anti-diabetic Properties of the Aqueous Leaf Extract of Bougainvillea glabra (Glory of the Garden) on Alloxan-Induced Diabetic Rats Grace I. Rec. Nat. Prod. 3:4 (2009) 187192.

29. Praseeja Cheruparambath, Ayisha banu.C and Manogem E.M .Evaluation of Bougainvillea glabra (Nyctaginaceae) leaf extract and chitin synthesis inhibitor, flufenoxuron against Spodoptera mauritia BOISD. (Lepidoptera: Noctuidae): on larvicidal and pupicidal activity. Int. J. Pure App. Biosci. 3 (4): 147-153 (2015).

30. V.Gupta, M. Singhal, M.George, , L.Joseph. MICROSCOPY, ANTI-DIARRHOEAL AND REDUCING POWER OF PLANT EXTRACTS OF BOUGAINVILLEA GLABRA “SNOW WHITE”.Pharmacology online 3: 40-48 (2009).

31. V.Gupta, M. Singhal, M.George, , L. Joseph MICROSCOPY, ANTI-DIARRHOEAL AND REDUCING POWER OF PLANT EXTRACTS OF BOUGAINVILLEA GLABRA “SNOW WHITE” Pharmacology online 3: 40-48 (2009).

\section{BJMHR is \\ - Peer reviewed \\ - Monthly \\ - Rapid publication \\ - Submit your next manuscript at editor@bjmhr.com

